\title{
Hydrothermally altered and fractured granite hosting rare metals at gabal adara adatalob, south eastern desert, Egypt
}

\author{
Hassan Abd El Razek Aly Shahin, Masoud Salah Masoud \\ Nuclear Materials Authority, P. O. Box 530, El-Maadi, Cairo, Egypt \\ Email address: \\ Hassanshahin03@yahoo.com (H. A. E1 R. Aly Shahin), Masoudsalah288@yahoo.com (M.S. Masoud)
}

\section{To cite this article:}

Hassan A. A. Shahin and, Masoud S. Masoud. Hydrothermally Altered and Fractured Granite Hosting Rare Metal at Gabal Adara Adatalob, South Eastern Desert, Egypt. Earth Sciences. Special Issue: Hydrothermally Altered and Fractured Granite Host Rare Metal at Gabal Adara Adatalob, South Eastern Desert, Egypt. Vol. 3, No. 6-1, 2014, pp. 1-7. doi: 10.11648/j.earth.s.2014030601.11

\begin{abstract}
Gabal Adara Adatalob granite in the south Eastern Desert, Egypt represents a promising example for hydrothermally altered and fractured granite hosting rare metals and rare earths mineralization. This granite host or act as a source for the rare metals ( $\mathrm{Zr}, \mathrm{Y}, \mathrm{Nb}, \mathrm{Yb}$ and $\mathrm{Ga}$ ) and rare earths ( $\mathrm{La}, \mathrm{Ce}, \mathrm{Pr}, \mathrm{Nd}, \mathrm{Sm}$, and $\mathrm{Yb}$ ) mineralization. It forms isolated pluton crop out in the wadi Ed Direira area. It shows highly alteration and a strong enrichment in some rare metals and rare earths contents $(\mathrm{Zr}=1434, \mathrm{Y}=629, \mathrm{Nb}=258, \mathrm{Ga}=39, \mathrm{La}=262.18, \mathrm{Ce}=546, \mathrm{Pr}=71.91, \mathrm{Nd}=366.88, \mathrm{Sm}=101.46, \mathrm{Yb}=$ $8.12 \mathrm{ppm})$. Field radiometric measurements for this granite revealed that low uranium and thorium content. The radioactivity level reaches up to $10.1 \mathrm{ppm}(\mathrm{eU}), 24.2 \mathrm{ppm}(\mathrm{eTh})$ respectively. The chondrite normalized rare earth elements, trends indicate strongly fractioned rare earth element pattern with significant strong enrichment in light rare earth elements rather than heavy rare earth elements.
\end{abstract}

Keywords: Hydrothermally Altered, Gabal Adara Adatalob, Rare Metal, Eastern Desert

\section{Introduction}

Gabal Adara Adatalob granite is located at the southern extremity of the Eastern Desert of Egypt near the Sudan Frontier between Latitudes $22^{\circ} 22^{\prime} 27^{\prime \prime}$ and $22^{\circ} 24^{\prime} 11^{\prime \prime} \mathrm{N}$ and Longitudes $35^{\circ} 47^{\prime} 49^{\prime \prime}$ and $35^{\circ} 50^{\prime} 50^{\prime \prime}$ E. This area lies at a distance of about $65 \mathrm{~km}$ North West of Abu Ramad City. The studied area can be reached through Abu RamadShalateen asphaltic road, drive about $35 \mathrm{Km}$ from $\mathrm{Abu}$ Ramad City tell road mark $35 \mathrm{~km}$ and turn to the west along Wadi Diib about $30 \mathrm{Km}$ to Gabal Adara Adatalob. It forms an isolated pluton along wadi Ed Direira area (Figure 1\&2). The area was earlier studied by older authors, e.g. Ball [1], studied the topography and geology of the South Eastern Desert, Egypt. Hume [2] studied the fundamental Precambrian rocks of Egypt and Sudan. Geological Survey of Egypt [3] prepared geologic map on scale 1:250.000 for the basement rocks of Marsa Sha'ab area between Latitude $22^{\circ}$ $00^{\prime}-23^{\circ} 00^{\prime}$.

Recently, there is no any previous work about Gabal Adara Adatalob, but there is little previous work around Gabal Adara Adatalob area, e.g. Hussein [4] studied the geology of the Halaib area of the northern Red Sea Hills with reference to the
Sol Hamed basic complex. Fitches [5] studied the late Proterozoic ophiolite of Sol Hamed, NE Sudan. El Alfy et.al. [6] prepared geochemical exploration of Elba - Gerf area south Eastern Desert. Nasr et.al. [7] Studied the Tertiary alkaline rocks in Gebel Elba area south Eastern Desert.

Khaliad et.al. [8] studied the results of geochemical, geological and mineralogical exploration of Gebel Elba. Omar et.al. [9] prepared geochemical map sheet No. 36 NE L 1,2,3 Qash Amir area, south Eastern Desert, Egypt. Shahin [10] studied the occurrence of uraniferous iron and manganese oxide deposits in biotite granite north east Gabal El Sela area. He concluded that the uraniferous iron and manganese oxide deposits and the hydroxides associated with kaolinite may represent a gossan on the top of a vein-type Ubearing deposit.

The present work deals with geology, petrography, geochemistry and radioactivity of Gabal Adara Adatalob granite south Eastern Desert of Egypt. 


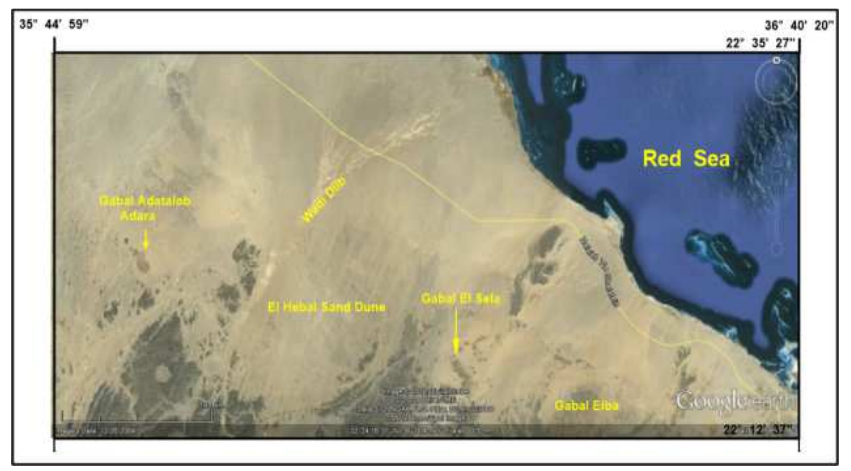

Figure 1. Google image for the studied area.

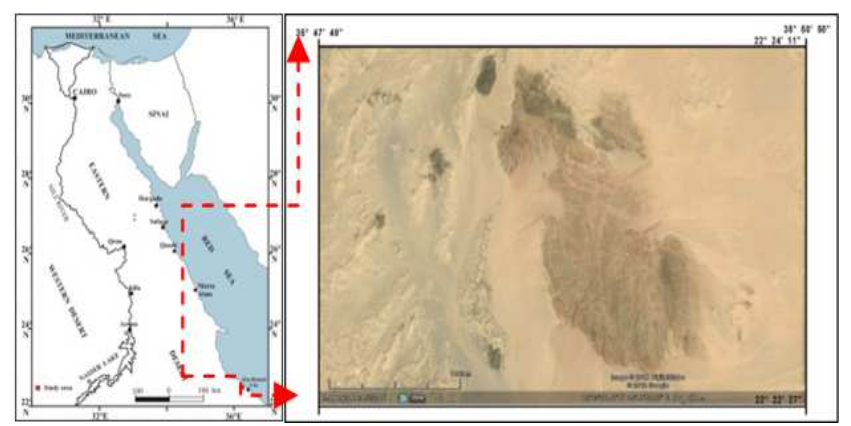

Figure 2. Location map and Google image forGabal Adara Adatalob granite.

\subsection{Geological Setting}

Gabal Adara Adatalob granite is moderate to low, elongated belt occurs as isolated pluton trending NNW-SSE (Figure 3). A detailed geologic study was carried out on this granite (Figure 4).This granite is highly altered, weathered, exfoliated, cavernous, coarse grained, pink to reddish pink in color and composed mainly of K-feldspar, quartz, plagioclase, biotite and some muscovite. Hematitic and kaolinitic alterations are prevalent, especially along the fractures and the intersection of faults (Figures 5\&6). It is characterized by the presence of manganese oxides filling joints and fractures indicating the enrichment of this granite by manganese mineralization (Figure 7).

Gabal Adara Adatalob granite is intersected by many fault sets.This granite display strongly fractured and jointed. The main tectonic trends affect this granite are NE-SW, NW-SE, $\mathrm{N}-\mathrm{S}$ and E-W major fault sets with contemporaneous silica injections (Figure 8). This quartz veins trending NE-SW and dipping $60^{\circ}$ to the $\mathrm{N}$. The intersection of these faults, mostly occupied by brecciated quartz veins (Figure 9). Different sets of joints are prevailing. The first set trending NE-SW and dipping $70^{\circ}$ to the NW and the second trending NW-SE and dipping $80^{\circ}$ to the NE.The emplacement of these injections along the fault zones were associated with high potential fluids which are indicated by the alteration halos. Hematitization and kaolinitization are the main alteration processes in this granite.

This granite is crosscut by different dykes and sheet. Finegrained granite occurs as sheets trending NW-SE (Figure 10). This fine-grained granite is mainly composed of quartz, K- feldspar, plagioclase, biotite and muscovite and characterized by the presence of extremely abundant manganese oxides filling joints and fractures. Basic dyke dissected this granite and occupy mostly the fault zone. N-S is the main trend of this dyke. Acidic dyke is also recorded in this granite trending in ENE-WSW direction. It is massive, fine-grained and ranges in color from light gray to brownish, grayish color, range in wide from 3-5 meters.

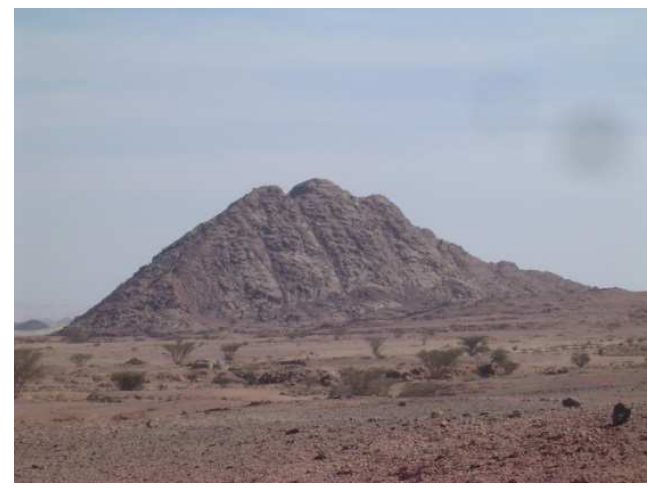

Figure 3. A photograph showing a general view for Gabal Adara Adatalob granite. Looking $N W$

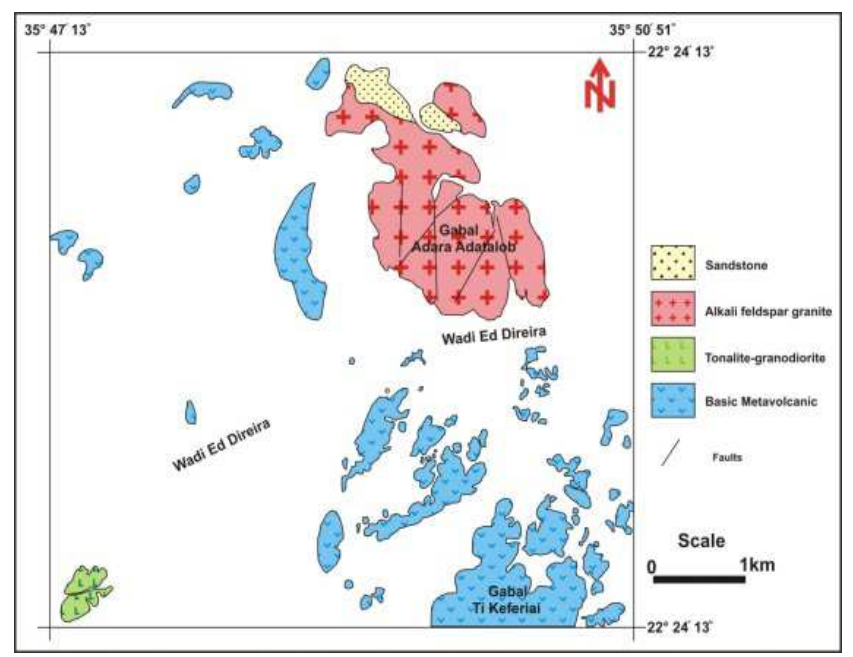

Figure 4. Geologic Map of Gabal Adara Adatalob area, South Eastern Desert, Egypt.

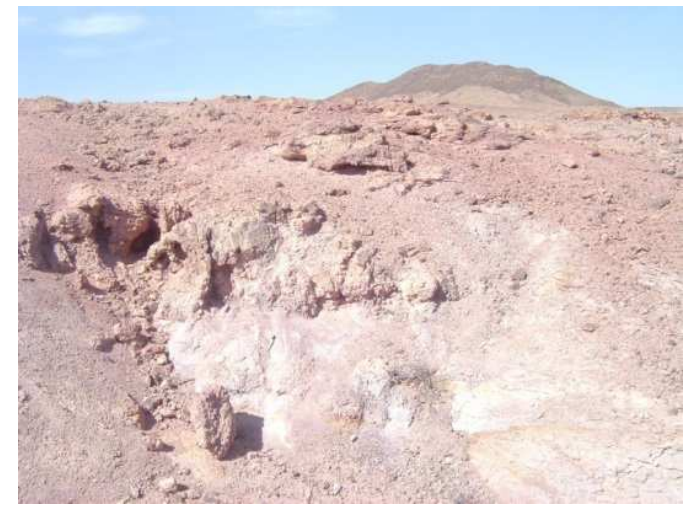

Figure 5. A photograph showing kaolinitic alterations at Gabal Adara Adatalob granite. Looking $N$ 


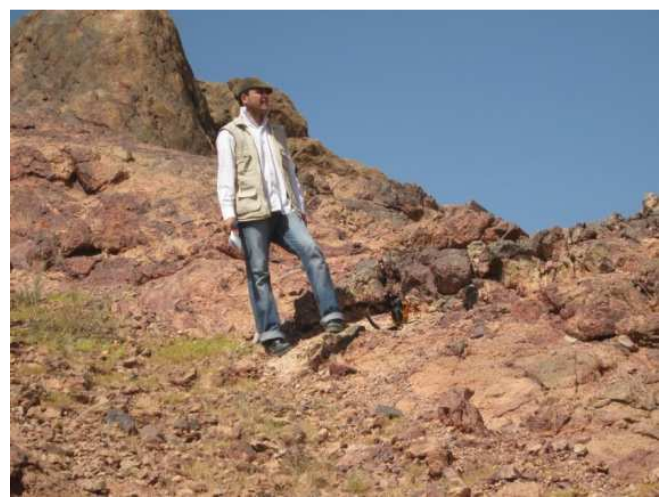

Figure 6. A photograph showing hematitic alterations at Gabal Adara Adatalob granite. Looking $N W$

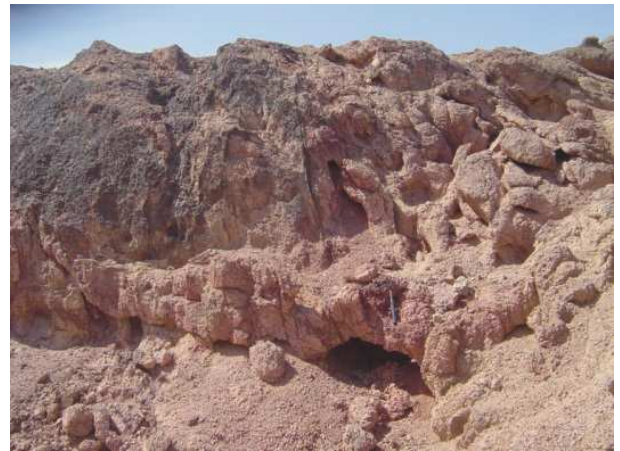

Figure 7. A photograph showing manganese oxides filling joints and fractures at Gabal Adara Adatalob granite. Looking $S W$

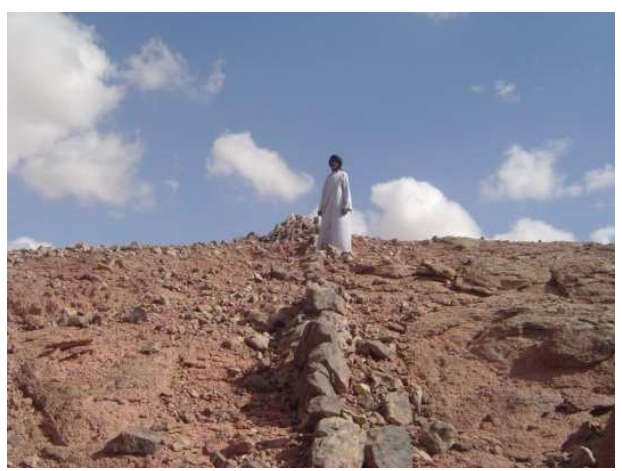

Figure 8. A photograph showing a quartz vein intruded the younger granite at Gabal Adara Adatalob granite. Looking NE

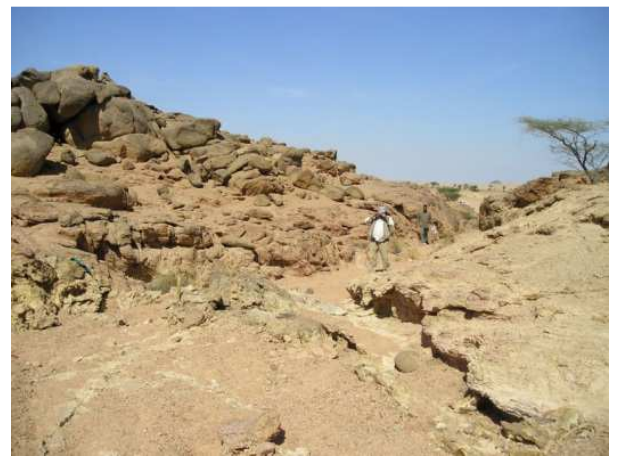

Figure 9. A photograph showing brecciated quartz vein along the fault plane. Looking $S W$

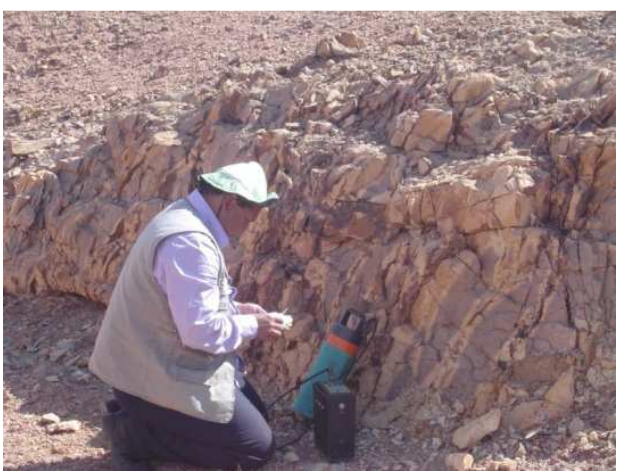

Figure 10. A photograph showing fine-grained granite occurring as a sheet cutting in Gabal Adara Adatalob granite. Looking E

Field relations revealed that they are intruded by sandstone with sharp contact. This sandstone rocks fine-grained, yellow to pinkish white in color, highly sheared, highly jointed and banded. This sandstone is found forming a cap cover the top part at the northern side of Gabal Adara Adatalob granite (Figures 11\&12). Gabal Adara Adatalob granite intrude the surrounding metavolcanic rocks with sharp intrusive contact (Figure 13). These metavolcanic rocks form moderate to high relief of gray to dark gray color and composed mainly of schistose chloritization metatuffs and metandesite.

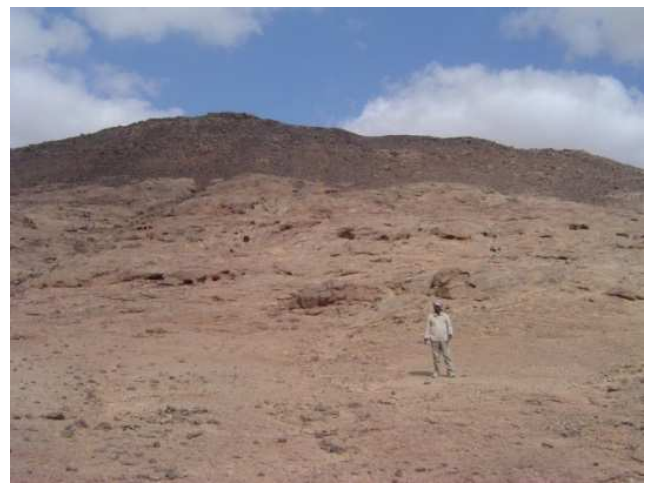

Figure 11. Aphotograph showing metamorphosed sandstone covers the top part in the northern side of the Gabal Adara Adatalob granite. Looking $N$

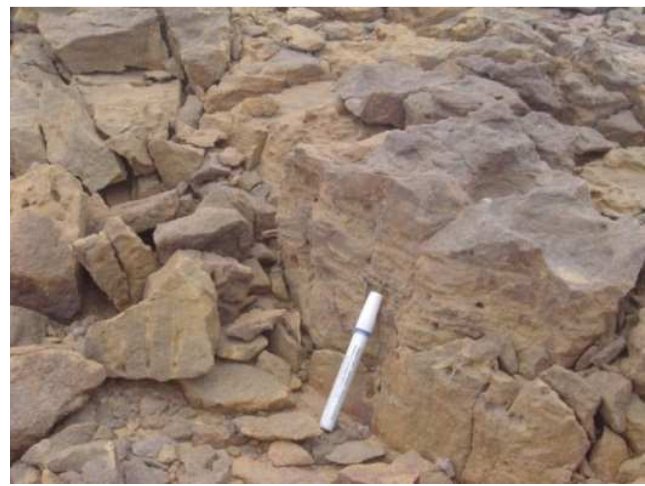

Figure 12. Closer view showing banding in the sandstone rocks. Looking NE 


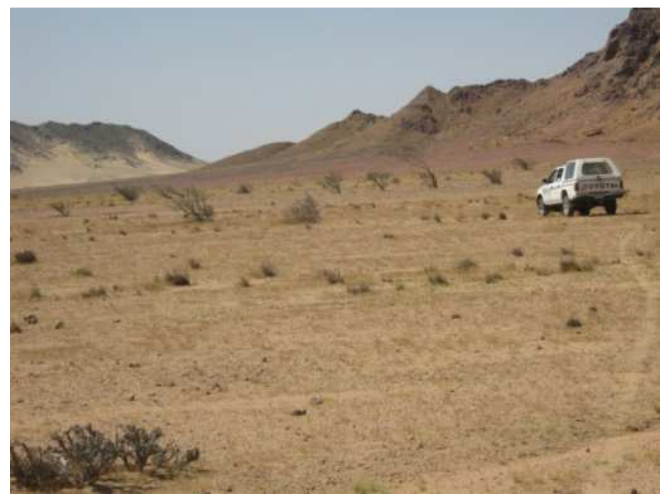

Figure 13. A photograph showing sharp intrusive contact between metavolcanics and Gabal Adatalob Adara granite. Looking NE

\subsection{Petrography}

Petrographically, Gabal Adara Adatalob granite is hypidiomorphic, inequigranular, non-porphyritic, coarsegrained and pink to reddish pink color. Microscopically, it is composed essentially of alkali feldspar comprises (orthoclase and perthite), quartz, alkali pyroxenite comprises (aegirine and acmite), minor plagioclase and biotite. The accessory minerals are zircon and iron oxides.

Orthoclase occurs as megacrysts up to $5.3 \times 2.1 \mathrm{~mm}$. Most of the orthoclase crystals show perthitic texture and still persevered the simple twinning plane (Figure 14A).

Perthite occurs as subhedral megacrysts up to $3.6 \times 2.4 \mathrm{~mm}$. Perthitic veinlets are the most predominate type of perthite in this granite.

Quartz occurs as subhedral to anhedral megacrysts up to 4 $\mathrm{x} 4.1 \mathrm{~mm}$ andsmall crystals up to $0.1 \times 0.2 \mathrm{~mm}$. It is found in two generations, the older fills the interstices between the Kfeldspar intergrowth with perthite crystals. Biotite represents the chief mafic minerals. It occurs as subhedral to anhedral crystals. These biotite crystals show strongly alteration to chlorite with the precipitation of iron oxide and carbonate (calcite) (Figure 14B).Aegirine occurs in large idiomorphic forms. It is characterized by its green color and strongly pleochroic(Figure 14C). Acmite occurs as prismatic crystals of dark green color and weakly pleochroic (Figure 14C). The accessory minerals are represented by few euhedral metamict zircon (Figure 13D), colorless fluorite and iron oxides (Figure 14E).

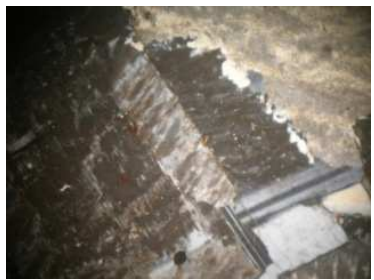

A

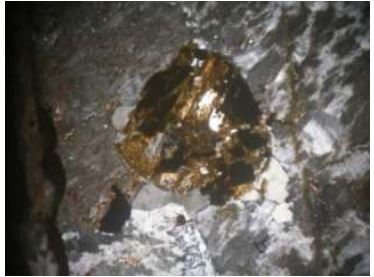

B

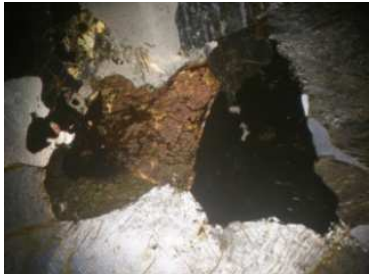

$\mathrm{C}$

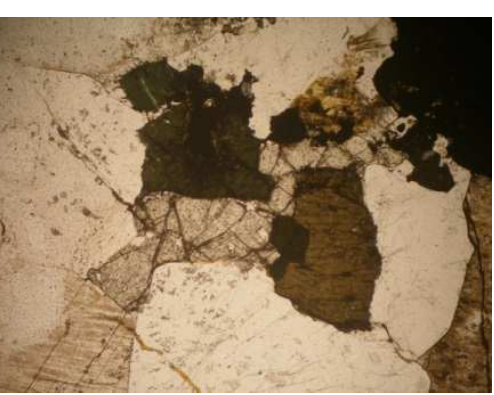

E

Figure 14. A. Photomicrograph shows simple twinning of Orthoclase perthite with some. C.N.X20. B. Photomicrograph shows Biotite corroded by the effect of hydrothermal solution with precipitation of iron oxide and carbonate (calcite). C.N. X20. C. Photomicrograph shows idiomorphic crystals of agerine and acmite(alkali pyroxene). C.N. X10. D. Photomicrograph shows metamict zircon associated with perthite and altered biotite. C.N. X20. E. Photomicrograph shows colorless fluorite with agerine and acmite crystals.PPLX10

\subsection{Radiometric Investigation}

Detailed field radiometric measurements using a portable four channel, gamma-ray spectrometer Model GR-230 were carried out along Gabal Adara Adatalob granite. The detailed field radiometric measurements revealed that low uranium content associated with Gabal Adara Adatalob granite. Radioactivity level was found to vary from $2.5 \mathrm{ppm}$ to 10 $\mathrm{ppm}(\mathrm{eU})$ and from $8.5 \mathrm{ppm}$ to $24 \mathrm{ppm}(\mathrm{eTh})$ respectively.

\subsection{Solid State Nuclear Track Detectors (SSNTDs)}

Solid state nuclear track detectors (SSNTDs) have been recognized by the IAEA as a standard method for estimation of radon, a throne and their daughter products in the environment. The detectors that are commonly used in environmental monitoring are generally made from cellulose nitrate (LR-115) and polycarbonates (CR-39).Alpha Tracketch Detectors (ATD) were installed for registering alpha particles from radon and radon decay products exhaled from the pink granite at Gabal Adara Adatalob, for a period 30 days, by using solid-state nuclear track detectors (polycarbonate films of type CR-39 Kodak). The CR-39 Kodak film fitted into the base of a plastic cup, and then the inverted cup is buried in a shallow hole $(30-50 \mathrm{~cm})$ deep for one month. The location of track etch cupsis recorded with a Global Positioning System (GPS) (Figures 15\&16).The obtained data were studied and counted under the microscope (Figure 17).The observed values of radon concentrations are given in Table (1).Radoncon centrations of Gabal Adara 
Adatalob granite are found to vary from $469 \mathrm{~Bq} / \mathrm{m}^{3}$ to 1442 $\mathrm{Bq} / \mathrm{m}^{3}$.The values are quite lower than that reported in other places in the Eastern Desert (e.g. El Sela area). This indicates the weak presence of radioactive occurrence buried beneath the surface of this granite.

Table 1. Track density and Radon Concentrations $\left(B q . / \mathrm{m}^{3}\right)$ for Gabal Adara Adatalob granite.

\begin{tabular}{lll}
\hline Cups No. & Track Density $\left(\mathbf{t r} / \mathbf{c m}^{\mathbf{2}}\right)$ & $\begin{array}{l}\text { Radon Concentrations } \\
\left(\mathbf{B q} . / \mathbf{m}^{\mathbf{3}}\right)\end{array}$ \\
\hline 247 & 4535.032 & 1426 \\
248 & 1490.446 & 469 \\
249 & 4331.21 & 1362 \\
250 & 4585.987 & 1442 \\
\hline
\end{tabular}

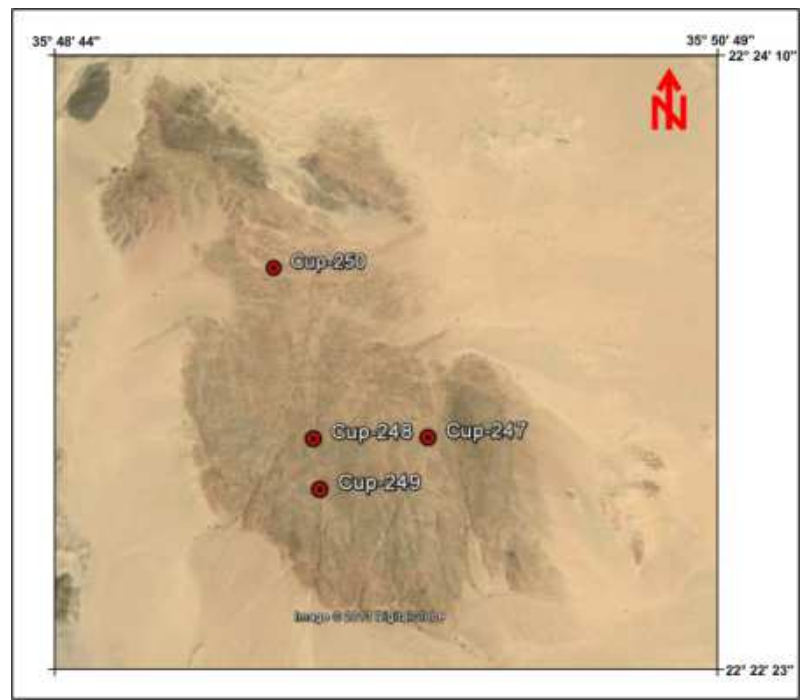

Figure 15. Google image showing the location of track etch plastic cup at Gabal Adara Adatalob granite.

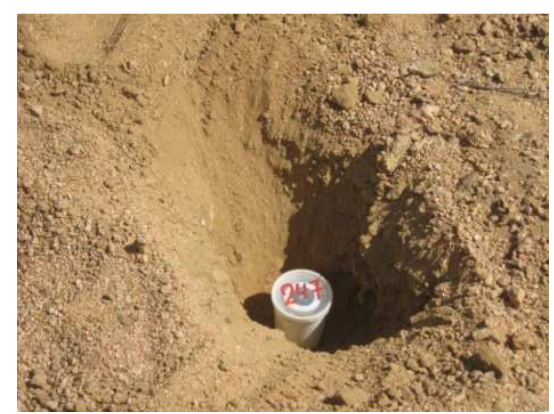

Figure 16. Track Etch plastic cup with polycarbonate film of type CR-39 Kodak is buried in shallow hole.

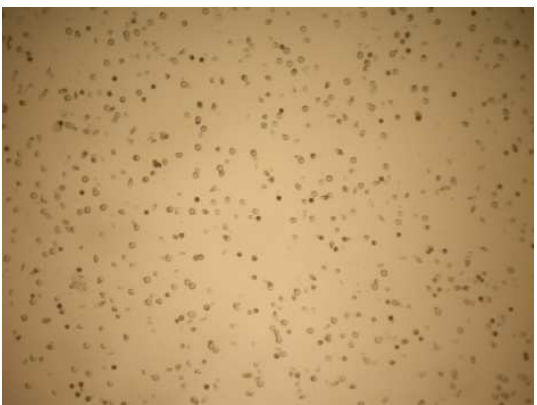

Figure 17. Optical micrograph of the CR-39 traces alpha particles released from radon. PPL $X 400$

\section{Materials and Methodology}

Thirty samples from the best exposures of the Gabal Adara Adatalob granite were collected for this study. From these, 14 samples were selected for thin sections to study the mineral constituents of this granite. Sixteen samples were selected and chemically analyzed for their trace elements and REE were analyzed with X-ray fluorescence analyzer (XRF) and inductively coupled plasma mass spectrometry (ICP- MS). Data of the trace elements and rare earth elements of the studied granite are listed in Tables (2\&3).

Table 2. Trace element composition (ppm) for Gabal Atadalob Adara granite

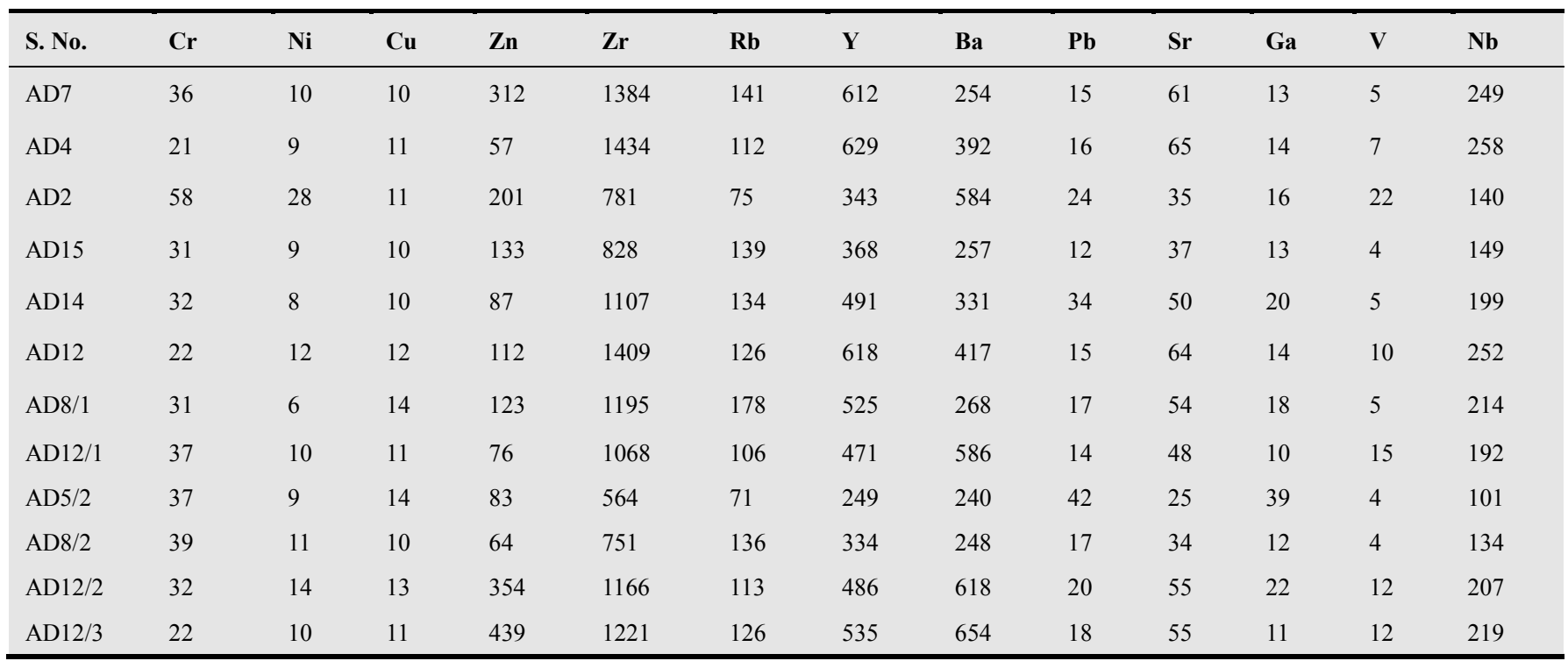


Table 3. Rare earth elements constituents (ppm) for Gabal Atadalob Adara granite.

\begin{tabular}{lllllllllllll}
\hline S. No. & Ad1 & Ad2 & Ad4 & Ad12 & Ad15 & Ad17 & Ad19 & Ad5/2 & Ad8/1 & Ad8/2 & Ad12/1 & Ad12/2 \\
\hline $\mathrm{La}$ & 4.34 & 45.26 & 152.6 & 40.20 & 38.99 & 81.82 & 104.5 & 6.60 & 68.38 & 7.87 & 19.46 & 262.8 \\
$\mathrm{Ce}$ & 10.72 & 112.9 & 364.1 & 99.53 & 56.41 & 179.4 & 178.6 & 24.74 & 157.3 & 19.45 & 44.54 & 546.0 \\
$\mathrm{Pr}$ & 2.25 & 15.66 & 52.11 & 14.20 & 8.53 & 25.29 & 20.39 & 2.60 & 23.46 & 2.45 & 6.68 & 71.91 \\
$\mathrm{Nd}$ & 15.44 & 88.43 & 265 & 76.57 & 42.87 & 132.2 & 107.2 & 12.21 & 121.4 & 9.98 & 33.67 & 366.9 \\
$\mathrm{Sm}$ & 5.20 & 26.76 & 75.63 & 21.60 & 11.67 & 36.14 & 22.61 & 3.75 & 33.72 & 3.50 & 9.39 & 101.5 \\
$\mathrm{Eu}$ & 8.29 & 1.82 & 1.82 & 1.75 & 3.98 & 3.27 & 2.31 & 4.60 & 1.86 & 4.53 & 3.34 & 4.54 \\
$\mathrm{Gd}$ & 3.49 & 12.49 & 14.89 & 9.94 & 12.22 & 13.83 & 16.51 & 5.45 & 9.92 & 4.81 & 6.46 & 22.19 \\
$\mathrm{~Tb}$ & 0.66 & 2.45 & 2.75 & 1.70 & 2.10 & 2.30 & 2.95 & 0.75 & 1.85 & 0.85 & 1.15 & 3.50 \\
$\mathrm{Dy}$ & 6.34 & 12.54 & 13.94 & 11.28 & 12.81 & 12.06 & 18.00 & 5.74 & 10.56 & 6.38 & 6.14 & 20.60 \\
$\mathrm{Ho}$ & 2.39 & 2.69 & 3.66 & 2.35 & 2.78 & 3.00 & 4.23 & 0.96 & 3.28 & 1.45 & 1.44 & 6.88 \\
$\mathrm{Er}$ & 4.85 & 6.65 & 5.98 & 5.94 & 6.95 & 4.97 & 9.62 & 2.82 & 7.06 & 4.98 & 3.91 & 9.38 \\
$\mathrm{Tm}$ & 0.60 & 0.95 & 1.05 & 0.70 & 0.95 & 0.62 & 1.15 & 0.35 & 1.00 & 0.92 & 0.60 & 1.30 \\
$\mathrm{Yb}$ & 3.16 & 5.67 & 6.43 & 4.50 & 8.12 & 4.30 & 5.92 & 2.13 & 4.18 & 7.85 & 4.51 & 6.36 \\
$\mathrm{Lu}$ & 0.33 & 1.03 & 0.68 & 0.59 & 1.04 & 0.56 & 0.67 & 0.26 & 0.48 & 1.15 & 0.69 & 0.94 \\
\hline
\end{tabular}

\section{Results}

\subsection{Trace Elements}

Concentrations of a wide variety of trace elements are shown in Table 2. Gabal Adara Adatalob granite is distinctive because of its generally higher concentrations of some incompatible trace elements. Zirconium contents range from less than $571 \mathrm{ppm}$ to $1434 \mathrm{ppm}$. Yttrium ranges from about $249 \mathrm{ppm}$ to about $629 \mathrm{ppm}$. Niobium abundance ranges from about $101 \mathrm{ppm}$ to over $252 \mathrm{ppm}$. Gallium contents range from about $10 \mathrm{ppm}$ to about $39 \mathrm{ppm}$. The higher content in some rare metal and rare earth mineralizations in this granite due to several normal fault movements accompanied with hydrothermal fluids lead to the intense alteration of Gabal Adara Atadalob granite represented by Hematitization and kaolinitization alterations. These alterations, act as a trapped phase and carrier for some rare metal and rare earth mineralizations enriched this granite. So, these hydrothermal fluids are potentially important in the dissolution, transportation and precipitation of these elements in this granite.

\subsection{Rare Earth Elements (REEs)}

The REEs data of the Gabal Adara Adatalob granite are normalized against chonderite values of Henderson (1996). Table (3) shows the REE chonderite for the studied granite.

Figure (18) shows the normalized REEs patterns for the Gabal Adara Adatalob granite. The REE plots of all samples of the Gabal Adara Adatalob granite showing distinct differences exist in the nature and size of Eu anomaly. The first cluster (red color) shows distinct strong enrichment in LREE and increasing decrease in HREE with moderate negative Eu anomaly. The second cluster (pink color) shows progressively decrease in LREE and depletion in HREE with weak negative $\mathrm{Eu}$ anomaly. The third cluster (blue color) shows a slight increase in LREE enrichment and a flat pattern in HREE with positive EU anomaly.

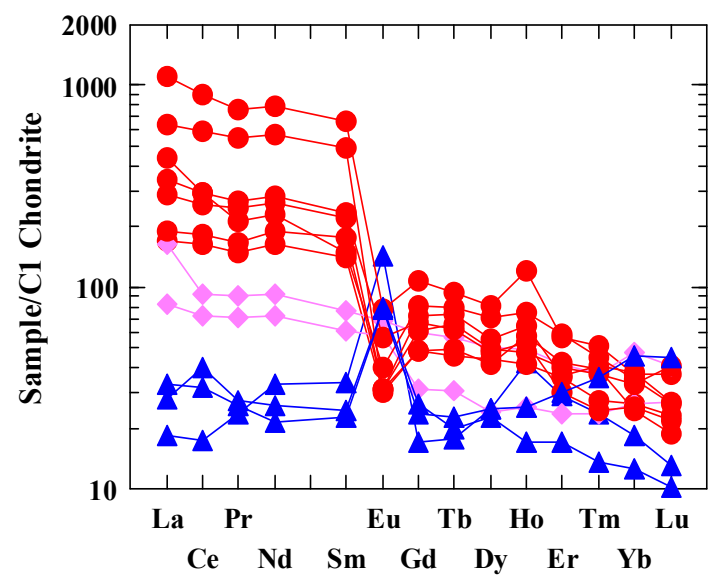

Figure 18. Chonderite normalized pattern for the studied Gabal Atadalob Adara granite.

\section{Conclusions}

Hydrothermal processes enriched by rare metal mineralization accompanied with event of an intensive tectonic structure affected Gabal Adara Atadalob granite. This event is marked by a deformation, fault rocks filled by brecciated quartz vein and alteration phase, which promoted fluids mobilization and deposition. This suggests that mobilization of fluids that formed rare metals mineralization at Gabal Adara Atadalob granite is mainly tectonicallycontrolled. These hydrothermal fluids processes played an important role in the dissolution, transportation and precipitation of these elements ( $\mathrm{Zr}, \mathrm{Y}, \mathrm{Nb}, \mathrm{Ga}$ and REE) in this granite. Geochemical data indicating strong enrichment in some rare metal contents $(\mathrm{Zr}=1434, \mathrm{Y}=629, \mathrm{Nb}=258$, and $\mathrm{Ga}=39 \mathrm{ppm})$. The chondrite normalized rare earth elements patterns indicate strongly fractioned rare earth 
elements pattern with significantly enriched of LREE and depletion in HREE at Gabal Adara Atadalob granite.

\section{References}

[1] Ball, J. (1912):The geography and geology of south eastern Egypt. Geol. Surv., Cairo. P. 394.

[2] Hume, W.F. (1935): Geology of Egypt. II. The fundamental Precambrian rocks of Egypt and Sudan: Part I, The metamorphic rocks : $1-300$, Part II, The later plutonic and minor intrusive rocks : 301-688, Part III, The minerals of economic value : 689 - 900, Geol. Surv. Egypt.

[3] Egyptian Geological Survey, (2002): Marsa Shaab Quadrangle map, Scale, 1:250,000. Geol. Surv. Egypt, Cairo.

[4] Hussein, I. M. (1977): Geology of the Halaib area of the northern Red Sea Hills, Sudan, with reference to the Sol Hamed basic complex. M. Sc., Portsmouth Polytechnic, England.

[5] Fitches, W.R.; Graham , R.H.; Hussein, I.M.;Ries, A.C.;
Shackleton, R.M. and Rice, R.C. (1983): The Late Proterozoic affiliate of Sol Hamed, NE Sudan Precambrian Research, V. 19, PP. 385 - 41 , Elsevier Amsterdam.

[6] El Alfy, Z.; Bagddady, M.; Awaga, G.; Morsei, A.; Ramadan, T. and Abdallah, M. A. 1994. Geochemical exploration of Elba - Gerf area south Eastern Desert, Egypt, Geol. Surv., Cairo (unpublished report).

[7] Nasr, B.B. and Youssef, M. 1995. New occurrences of Tertiary alkaline rocks at Gebel Elba area South Eastern Desert, Egypt. Annals of Geol. Surv. V. XX. . PP.871 - 873.

[8] 8] Khalaf I.M. (2005): Geology of the area around G. Qash Amir with special emphases on the granitic rocks, south Eastern Desert, Egypt. Egypt J Geol 49:49-64

[9] Omar, M. A.; Said, S. M.; Morsi, A. M. and Abu EL Labn, S. A. (1998): Geochemical map sheet No. 36 NE L 1,2,3 Qash Amir area, south Eastern Desert, Egypt. Geol. Surv. , Cairo ( unpublished report ).

[10] Shahin A.A. (2011): Occurrence of uraniferous iron and manganese oxides in biotite granite North East Gabal El Sela area, South Eastern Desert, Egypt. Arabian Journal of Geosciences, Vol. 6, Issue 7, pp 2245-2259. 